Pacific Northwest

NATIONAL LABORATORY

Proudly Operated by Battelle Since 1965

\title{
Modeling to Support the Development of Habitat Targets for Piping Plovers on the Missouri River
}

\section{May 2015}

KE Buenau 


\title{
DISCLAIMER
}

This report was prepared as an account of work sponsored by an agency of the United States Government. Neither the United States Government nor any agency thereof, nor Battelle Memorial Institute, nor any of their employees, makes any warranty, express or implied, or assumes any legal liability or responsibility for the accuracy, completeness, or usefulness of any information, apparatus, product, or process disclosed, or represents that its use would not infringe privately owned rights. Reference herein to any specific commercial product, process, or service by trade name, trademark, manufacturer, or otherwise does not necessarily constitute or imply its endorsement, recommendation, or favoring by the United States Government or any agency thereof, or Battelle Memorial Institute. The views and opinions of authors expressed herein do not necessarily state or reflect those of the United States Government or any agency thereof.

\author{
PACIFIC NORTHWEST NATIONAL LABORATORY \\ operated by \\ BATTELLE \\ for the \\ UNITED STATES DEPARTMENT OF ENERGY \\ under Contract DE-AC05-76RL01830 \\ Printed in the United States of America \\ Available to DOE and DOE contractors from the \\ Office of Scientific and Technical Information, \\ P.O. Box 62, Oak Ridge, TN 37831-0062; \\ ph: (865) 576-8401 \\ fax: (865) 576-5728 \\ email: reports@adonis.osti.gov \\ Available to the public from the National Technical Information Service, \\ U.S. Department of Commerce, 5285 Port Royal Rd.., Springfield, VA 22161 \\ ph: (800) $553-6847$
fax: $(703) 605-6900$ \\ email: orders $@$ ntis.fedworld.gov \\ online ordering: http://www.ntis.gov/ordering.htm
}

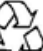

This document was printed on recycled paper.

(9/2003) 


\section{Modeling to Support the Development of Habitat Targets for Piping Plovers on the Missouri River}

KE Buenau

May 2015

Prepared for

the U.S. Department of Energy

under Contract DE-AC05-76RL01830

Pacific Northwest National Laboratory

Richland, Washington 99352 


\section{Summary}

This report describes analyses done in support of the establishment of quantitative targets for piping plovers on the Missouri River using predictive numerical models for emergent sandbar habitat and piping plovers developed for the Missouri River Effects Analysis. Several approaches were considered and modeled: current operations of the reservoirs to serve as a reference (Existing Conditions), an unregulated hydrograph to simulate historical conditions (Unregulated), a scenario where dams were present but not operated (No-Operations), and a scenario where the amount of habitat necessary to provide a desired level of population viability ( $5 \%$ risk of extinction in 50 years) was constructed (Calibrated Target). These scenarios were compared in terms of the distribution of standardized habitat produced, the proportion of time available habitat exceeded a given acreage, and the risk of quasi-extinction for plover populations. Sensitivity analyses were also conducted to demonstrate the effects of initial population size and target habitat acreage on extinction risk and the effects of viability criteria on habitat targets. Limitations and uncertainties in the modeling, including caveats on the use of these models to estimate historical conditions and the availability of information to build a metapopulation model are discussed. The challenges inherent in setting population targets and a possible alternative approach to assessing management alternatives in terms of population effects are also included. 


\section{Contents}

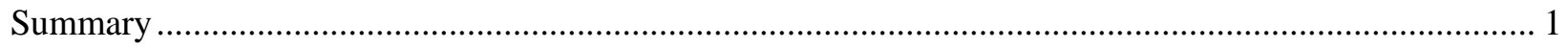

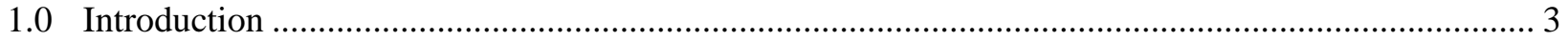

1.1 Approaches to Deriving Population and Habitat Targets..................................................... 4

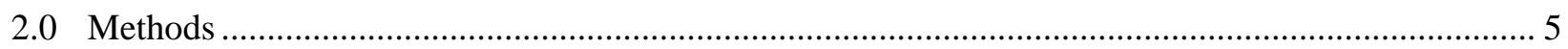

2.1 Modeling Framework and Spatial Structure .......................................................................... 5

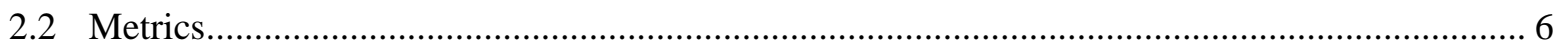

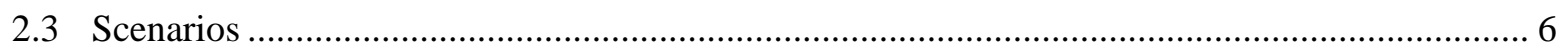

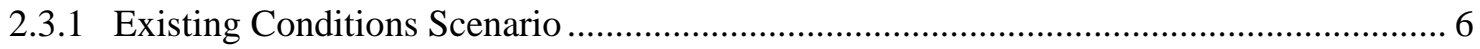

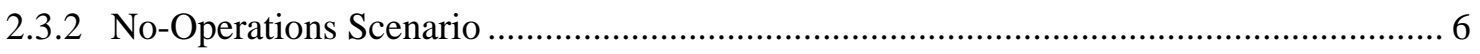

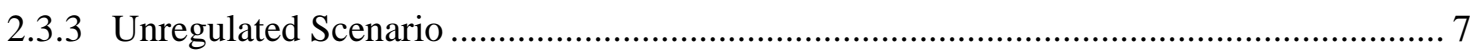

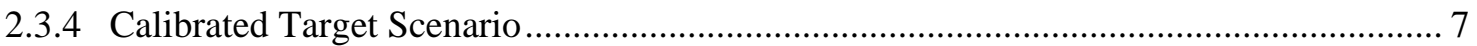

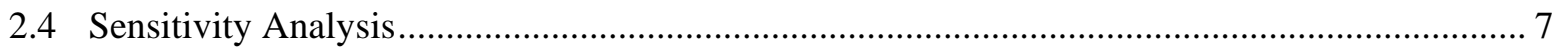

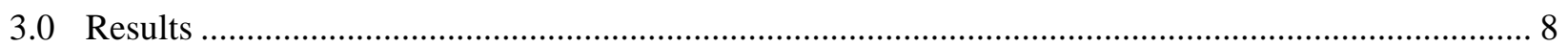

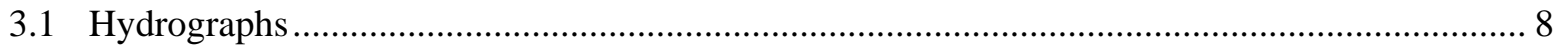

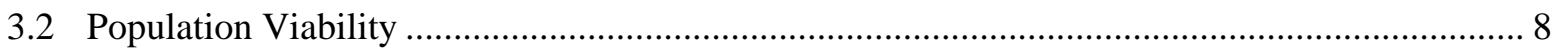

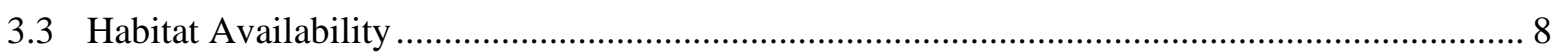

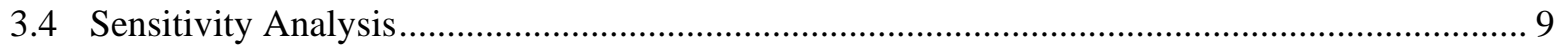

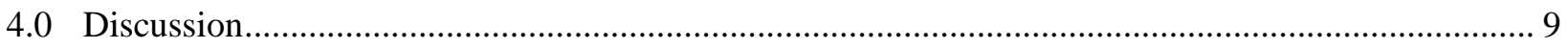

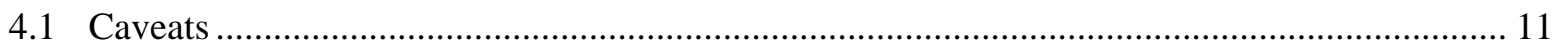

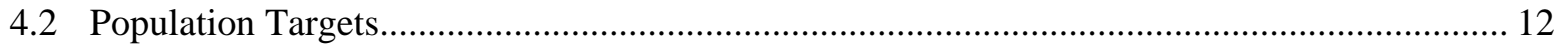

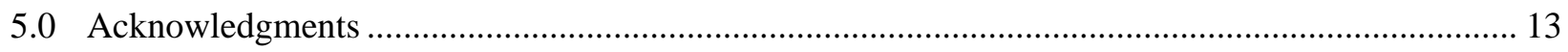

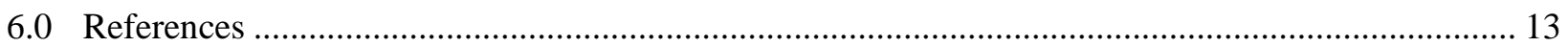




\subsection{Introduction}

A fundamental component of the Missouri River Recovery Management Plan (MRRMP) under development by the U.S. Army Corps of Engineers (USACE) for piping plovers, least terns, and pallid sturgeons is the establishment of quantitative targets for as many of the stated objectives of the program as possible. Objectives and targets are primarily the responsibility of the U.S. Fish and Wildlife Service (USFWS) in coordination with the USACE and with the assistance of technical and subject matter experts conducting the effects analysis (EA) for the MRRMP. The role of technical and subject matter experts is to provide the scientific context and analytical tools necessary for the agencies to make informed decisions, using the best available science, about objectives and targets. This report outlines the technical background, describes model configurations and scenarios, and presents results of model analyses conducted in support of the development of habitat targets for piping plovers.

The objectives for piping plovers, drafted by the USFWS in 2013, are as follows:

"Fundamental Objective: Avoid jeopardizing the continued existence of the piping plover from the US Army Corps of Engineers actions on the Missouri River.

Sub-objective 1: Maintain a total population number of Missouri River birds that keep the population resilient on the Missouri River in the long term.

Sub-objective 2: Maintain a long-term trend in population growth that is at least stable.

Sub-objective 3: Increase and maintain the success of breeding pairs on the Missouri River.

Sub-objective 4: Maintain a geographic distribution of plover in the river and reservoirs in which they currently occur."

The EA for piping plovers and least terns (Buenau et al. 2014) assessed the effects of current and potential management actions on the dynamics of emergent sandbar habitat (ESH), reservoir shoreline habitat, and piping plover and least tern populations. The EA includes predictive numerical models that represent the current state of science regarding Missouri River habitat and bird populations. These models and associated EA findings were used to develop the scientific basis for quantitative habitat targets. This report describes the scientific basis and the scenarios and calculations used in target development. The analyses described in this report were done in coordination with the USFWS to ensure its information needs were met, but the technical work was done independently by the author. Several portions of the analyses herein were done with assistance from EA hydrology and geomorphology team members who provided models and model outputs for reservoir simulation and habitat modeling. Decisions about how to use this information to establish the targets are outside of the domain of the EA and thus are not discussed in this document. Those decisions will be reported separately by the USFWS.

The spatial scope of the analyses in this document is the Missouri River Mainstem System (MRMS) throughout the range currently managed for piping plovers: from the upper bounds of Lake Sakakawea (river mile $[\mathrm{RM}] 1$,568) through Ponca, Nebraska (RM 753). The absence of habitat on Lake Sharpe and Lake Francis Case, between Oahe and Fort Randall Dams (RM 1,072-880) creates a dispersal barrier between the northern and southern portions of the piping plovers' MRMS range. Consequently, the range has been divided into two subpopulations (USFWS Piping Plover Recovery Team, pers. comm.). The northern region consists of riverine habitat on Garrison Reach and shoreline habitat on Lake Sakakawea and Lake Oahe. The southern region consists of riverine habitat on Fort Randall and Gavins Point Reaches, as well as the sandbars in the delta of Lewis and Clark Lake, which does not provide reservoir shoreline habitat. 


\subsection{Approaches to Deriving Population and Habitat Targets}

Several approaches have been considered for the development of habitat and/or population targets for piping plovers on the Missouri River, including use of historical reference conditions, scenarios without dam operations, and population viability modeling. Because of the nature of habitat on the Missouri River and data limitations, there was no single approach that could be identified as superior in addressing all aspects of the problem; all three approaches were explored in order to provide as much information as possible to the decision.

The historical reference approach focuses on determining the impact of the actions that changed the natural character of the river. The historical reference provides a target, and the resulting deficit between the target and the current state of the affected habitat and population needs to be remedied through habitat restoration and/or population recovery actions. For the MRMS, the relevant action was the construction and operation of the mainstem dams. The historical reference approach for the MRMS would require knowing, or reliably estimating, the amount of habitat and the number of plovers typically present prior to the construction and operation of the dams. Such information is not available; population surveys did not begin until 1986 and habitat assessments were very sporadic and of limited scope prior to 2006. In the absence of sufficiently comprehensive historical surveys, models must be used to estimate habitat availability and associated population sizes. The models designed for the EA estimate ESH availability as a function of flow and ambient area through the processes of erosion, deposition, and seasonal inundation. While these models can be used to estimate historical habitat conditions, they are parameterized using data reflecting contemporary conditions-hydrology, channel morphology, and sediment budgets — and must be used with caution when extrapolated outside of those conditions.

A related but distinct approach reflects the focus of the 2000 and 2003 Biological Opinions (USFWS 2000; 2003) on the operations and maintenance of the mainstem dams rather than their construction. An approach to estimating the impact of the dam operations, then, is to estimate the conditions that would result if the dams were present but not operated. This approach also relies on ESH models that reflect contemporary conditions, but this limitation is reasonable if viewed as a model of the current system with the presence, but not operation, of the dams.

The population viability approach, commonly used in species recovery or conservation plans, is to determine the population size required to ensure that a specified risk of extinction over a specified time frame is not exceeded. The recovery team for the Great Plains population of piping plovers is using a population viability model (McGowan et al. 2014) to calculate an initial population size that, when modeled, has less than a $5 \%$ risk of quasi-extinction (population size less than 50 adults) in 50 years (Piping Plover Recovery Team, pers. comm.). The USFWS requested that this viability criterion be used in this analysis.

Population viability analyses frequently rely on the long-term sensitivity of extinction risk to initial population size. Such sensitivity is commonly the case in density-independent population models and may be the case in density-dependent population models where habitat, and thus carrying capacity, is constant over time. Missouri River plovers, however, exhibit density-dependent population dynamics in a highly variable environment. Carrying capacities change continually, reflecting the dynamic nature of flow-driven habitat availability. In such situations, extinction risk can be much more dependent upon the habitat regime than the initial population size, particularly over multi-decadal time scales. Consequently, if the goal is to achieve a desired population viability metric, habitat targets may be more readily defined than population targets.

Each of the three approaches outlined above has strengths and weaknesses for application in determining plover habitat or population targets for the MRRMP. All three approaches were exercised and provided to 
the USFWS for their consideration while developing targets for piping plovers. The methods and results for each approach and their technical advantages and limitations are described below.

\subsection{Methods}

\subsection{Modeling Framework and Spatial Structure}

The modeling framework used to calculate targets was originally developed for the Missouri River EA for piping plovers and least terns (Buenau et al. 2014; Fischenich et al. 2014). Hydrological data were generated using the Hydrologic Engineering Centers Reservoir Simulation (HEC-ResSim) software implemented for the entire MRMS. HEC-ResSim uses historical basin runoff data and rules sets defining reservoir operations and depletions to project reservoir inflows, outflows, and pool elevations as well as flows at additional points along the river. All hydrological runs used for this analysis used historical runoff from the period of record of 1930-2012. Reservoir operations were modeled as if the same operation rules were in effect for all years for each scenario. Monthly metrics (average and maximum reservoir outflows and elevations) were calculated from daily ResSim output for use in the habitat models. Habitat simulations used sequential 50-year subsets of ResSim output with the initial year selected at random for each replicate model run.

Habitat and plover populations were modeled in spatial units of reservoirs and reaches. The default configuration was four riverine habitat reaches (Garrison, Fort Randall, Gavins Point, and Lewis and Clark Lake delta) and two reservoirs (Lake Sakakawea and Lake Oahe). Changes in this configuration to accommodate specific scenarios are described below.

The model of ESH on riverine reaches estimates the erosion and deposition of sandbars as a function of flow and ambient sandbar area and is described fully by Fischenich et al. (2014). The model was parameterized for Garrison, Fort Randall, and Gavins Point Reaches. These models were extended to other locations for the No-Operations and Unregulated scenarios as described below. The model outputs include standardized ESH, which is defined as ESH area above a reference plane for a fixed flow or pool elevation (31.6 kcfs for Gavins Point Reach, 30.5 kcfs for Fort Randall Reach, and 23.9 kcfs for Garrison Reach; Lewis and Clark Lake is standardized to an elevation of 1,206 ft) and ESH available for nesting, which is determined by adjusting the standardized ESH acreage to reflect the area above a reference plane corresponding to the water surface at the maximum July flow each year.

Reservoir habitat was modeled implicitly through reservoir elevation metrics (feet of shoreline above current water elevation that was inundated for at least 160 days in the previous 2 years; change in water elevation during the nesting season; Buenau et al. in prep) that predict plover fledgling production (Anteau et al. 2012; Anteau et al. 2014). A model exists to predict acreage of suitable habitat on the reservoirs (Anteau et al. 2014), but it does not cover a sufficient range of elevations to accommodate those included in the entire period of record used in this analysis. Analyses of plover productivity for the reservoirs undertaken as part of the EA suggested that acreage was not as good a predictor of observed fledgling production as the water-level metrics. The metric of elevation inundated in the previous 2 years was used to estimate the vertical extent of shoreline free of vegetation and was based upon metrics used in the reservoir acreage model (Anteau et al. 2014).

The population model for plovers is based upon Buenau et al. (2013), updated to reflect the most current demographic rate estimates available (Buenau et al. 2014). It includes the production of fledgling plovers by nesting adults, juvenile and adult survival, and dispersal between reaches and regions. 
Initial conditions for the model, unless otherwise specified, were the 2014 estimates of population size (1,116 adults and 626 fledglings) and standardized habitat acreage (2,293 acres in Gavins Point Reach, 1,035 acres in Lewis and Clark Reach, 1,250 acres in Fort Randall Reach, and 4,647 acres in Garrison Reach, for a total of 6,613 acres).

With the exception of the daily flow and pool elevation values output from the ResSim models, all models included estimation error. Plover population models also included environmental (temporal) stochasticity, demographic stochasticity, and observation error. To incorporate these forms of variability, all model output was produced using Monte Carlo simulations with 5,000 replicates per scenario, with results presented as distributions that characterize the variability in predictions produced by the different forms of stochasticity.

\subsection{Metrics}

Population outcomes are represented as the probability of quasi-extinction over time, defined as the proportion of 5,000 model replicates in which populations fell below 50 adults on or before each year in the model replicate. The quasi-extinction threshold of 50 was selected in accordance with the piping plover recovery plan (Piping Plover Recovery Team, pers. comm.). ESH results are presented below as the distribution of standardized ESH predicted by the models (median, 2.5th percentile, and 97.5th percentile acreages) and the distribution of available habitat in the form of exceedance plots. Metrics were calculated for the northern and southern regions separately and combined.

\subsection{Scenarios}

The target analysis and estimations were based on four scenarios. The following section describes them briefly. Their attributes and further specifications are summarized in Tables 1 and 2. ${ }^{1}$

\subsubsection{Existing Conditions Scenario}

The Existing Conditions scenario reflected the current operations and spatial configuration of the MRMS. Reservoir operations followed the current Master Manual (USACE 2006) operating rules with no additional management for threatened and endangered species. This condition was used as a reference for understanding the results of the other scenarios.

\subsubsection{No-Operations Scenario}

The No-Operations Scenario was designed to simulate the hydrology and ESH dynamics that would occur if the dams were in place but not operated. In this scenario, all rules are removed from the ResSim model so that the natural hydrograph is constrained only by the physical limitations of the outlet works in each dam. The starting condition for each simulation assumed the reservoirs were drawn down to their dead pools (the water below the elevation of the outlet works that cannot be drained). Water elevation in the remaining reservoirs fluctuated in direct response to inflows and capacity of outlet works, as did river stage (greater magnitude and frequency of variability than seen in normal reservoir operations). In this scenario, the segments of the river no longer inundated within reservoirs were treated as riverine. Upper Lake Sakakawea was modeled as a river reach using the Garrison ESH model, upper Lake Oahe was

\footnotetext{
${ }^{1}$ Tables and figures cited in the narrative are included in numerical order — tables first, then figures—at the end of the report.
} 
modeled as part of an extended Garrison Reach, and all of the Lewis and Clark Lake segment was modeled using the Fort Randall ESH model (see Table 2 for details). Lake Sharpe and Lake Francis Case were not included in this scenario. The ESH models were based on contemporary hydrology, channel morphology, and sediment budgets; thus, this scenario represents a condition in which reservoir operations ceased in the current day.

\subsubsection{Unregulated Scenario}

ResSim includes an option to run the modeled system as "unregulated," i.e., routing runoff through the system without the presence of dams or reservoirs. This unregulated scenario was intended to represent the effects of a natural hydrograph on ESH dynamics. Because the unregulated model was based on the absence of reservoirs, all segments of the river from the upper bounds of the contemporary Lake Sakakawea to Ponca were modeled as riverine, using the ESH models developed for the most similar river reaches (see Table 2 for details). This included Lake Sharpe and Lake Francis Case, modeled using the Fort Randall ESH model. As with the No-Operations scenario, the ESH models were parameterized using data reflecting current conditions and thus do not reflect actual historic conditions. The associated estimation error is unknown.

\subsubsection{Calibrated Target Scenario}

The Calibrated Target scenario determined how much habitat would be necessary to support the plover populations at a desired level of viability. The model was the same as the Existing Conditions scenario, except for the addition of mechanical ESH creation. ESH construction was implemented in the ESH model by adding standardized ESH acres during December (actual habitat construction may occur during the fall and/or spring; this approach averages the two seasons). Construction was specified with an acreage target for each riverine reach, excluding Lewis and Clark Lake. In each year of each model replicate the model estimated the amount of ESH that needed to be constructed to ensure that standardized habitat would be at or above the target in the following year, for a desired level of confidence. Because future flows are unknown, the amount of ESH that needed to be built had to be estimated from a distribution of possible flows and consequent ESH dynamics in the following year. Therefore, given a target acreage in year $t$, the ESH model estimated how much habitat is needed in year $t-1$ such that at least $50 \%$ of the time the standardized habitat acreage would be met or exceeded. In the case of high reservoir releases, such as in 1997 or 2011, habitat would be created by high flows, generally in amounts that exceed the targets. In such instances, habitat construction did not recur until the standardized ESH again approached target levels. Because of these incidental flow creation events, the actual median acreage of standardized habitat over time predicted by the model exceeds the acreage that the model used to calculate construction amounts. Various ESH targets were used in the model until the desired population persistence was met.

\subsection{Sensitivity Analysis}

Two sensitivity analyses are included in this report. The first assessed the sensitivity of quasi-extinction risk to initial population size and habitat targets. The initial population size in 2014 and the Calibrated Target were used as starting points, then a range from $20 \%$ to $200 \%$ of those values using $20 \%$ increments was run through the model. Each combination of initial population size and habitat target was used to calculate the proportion of simulations that reached quasi-extinction in 50 years. 
The second sensitivity analysis evaluated two alternative population viability criteria: a $10 \%$ risk of quasiextinction over 50 years and a 5\% risk of quasi-extinction over 100 years. Habitat targets were calculated for both alternative criteria.

\subsection{Results}

\subsection{Hydrographs}

Sample time periods from the discharge hydrographs for the Existing Conditions, No-Operations, and Unregulated scenarios are shown in Figure 1 and Figure 2 for Gavins Point and Garrison Dams. Figure 3 compares the hydrograph between reaches for each scenario. The Unregulated scenario had the highest peak discharges during peak-runoff months in the spring and early summer, with considerable variability between years and between drought and high-water intervals. The No-Operations scenario had peaks at the same time as the Unregulated scenario, but they were of smaller magnitude and longer duration because of the limitations of water flow through the outlet works of the dams. The difference between the two scenarios was more pronounced in Gavins Point Reach because the water had passed through four more dams at that point. The two scenarios' discharges at low-water periods were similar.

The pattern of the regulated flows in the Existing Conditions scenario was notably different from the previous two scenarios. Spring peaks were strongly reduced or absent, and moderate flows continued into the fall, with excess water in some years evacuated later in the fall. Releases from Garrison Reach showed little intra-annual variability and low inter-annual variability except in years when runoff was especially high. Discharges in Gavins Point Reach showed more variability within and between years, but far less than in the No-Operations or Existing Conditions scenarios.

\subsection{Population Viability}

Under existing conditions, the overall plover population had a 0.082 probability of quasi-extinction after 50 years, while the populations in the northern and southern regions had a 0.13 and 0.46 probability of extinction, respectively (Figure 4). In the Unregulated scenario, the quasi-extinction probability was 0.038 overall, 0.060 in the northern region, and 0.15 in the southern region. The No-Operations scenario had the lowest probabilities of quasi-extinction with probabilities of 0.001 overall, 0.0044 in the northern region, and 0.013 in the southern region.

The Calibrated Target scenario was adjusted to be as close as possible to a 0.05 probability of quasiextinction in both regions. This produced quasi-extinction probabilities of 0.012 overall, 0.049 in the northern region, and 0.047 in the southern region.

\subsection{Habitat Availability}

The distribution of standardized habitat varied considerably across the four scenarios (Table 3). The Existing Conditions scenario had the least habitat available with a median of 768 acres overall, 106 acres in the northern region, and 370 in the southern region. The 95\% confidence interval includes 0 acres for the north and 3 acres for the south. The No-Operations scenario had the highest median acreages, with 12,477 acres overall, 8,630 acres in the north, and 2,782 acres in the south. The Unregulated scenario had fewer acres available at the median, but a broader distribution with a 95\% confidence interval including hundreds of thousands of acres for the entire river. The Calibrated Target scenario had roughly twice the 
median habitat acres as the Existing Conditions scenario in the river overall and in the southern region, and four times as much in the northern region. The upper bounds of the Calibrated Target scenario were similar to those of the Existing Conditions scenario because those acreages are driven by natural high flows rather than habitat construction. The lower end of the distribution, however, was much higher for the Calibrated Target scenario because the habitat construction provides fairly relatively stable quantities of habitat.

Habitat exceedance curves are shown in Figure 5. The Unregulated scenario generally had the highest proportional exceedance across the range of acreages for both regions, with the exception of acreages less than $\sim 600$ in the southern region and both regions combined. At acreages below 600, the Calibrated Target scenario provided the highest likelihood of habitat availability for the combined regions, while the No-Operations scenario provided the highest likelihood of habitat availability for the southern region. Overall, and in the southern region, the Existing Conditions scenario had the least habitat available across the entire range of acreages. In the north, however, the Existing Conditions scenario provided habitat below 1,500 acres more often than did the No-Operations scenario. The Calibrated Target scenario exceeded lower acreages more frequently than the Existing Conditions and No-Operations scenarios for the entire river and for the northern region, and more than the Existing Conditions and Unregulated scenarios for the southern region.

\subsection{Sensitivity Analysis}

Quasi-extinction risk for the entire river was more sensitive to target acreage than initial population size, with the greatest sensitivity at lower acreages and low variation above 1,000 target acres (Figure 6). In the northern region, quasi-extinction risk was somewhat more sensitive to population size than target acres, but a certain range of both was necessary to reach target extinction risks. In the southern region, however, extinction risk was almost entirely dependent on target acres, with very little of the variability in results explained by the initial population size.

The standardized acre distributions produced for the different extinction risk criteria are shown in Table 4. The median acres required to meet the target for the entire river decreases by 409 acres (29\%) if the quasi-extinction criterion was $10 \%$ instead of $5 \%$ over 50 years. The median acreages for the northern and southern regions decrease by 270 acres (63\%) and 175 acres (22\%), respectively. If the extinction risk was held at $5 \%$ but the time frame was extended to 100 years, the acreage needed for the entire river increases by 1,957 acres (58\%) and, for the northern and southern regions, 1,516 acres (78\%) and 379 acres (33\%), respectively. Exceedance plots for different viability criteria are shown in Figure 7.

\subsection{Discussion}

Extinction risk was highest for the Existing Conditions scenario (Figure 4), because flows of sufficient magnitude and duration to create habitat are relatively uncommon under current reservoir operating rules. The scenario included extended periods (10-15 years) where little to no ESH was available. Extinction risk was much lower in the northern region than in the southern region, because the reservoirs in the northern region provided some degree of habitat availability nearly every year-a stabilizing influence on the population. The riverine and delta reaches in the southern region frequently have little to no ESH available unless habitat-forming flows have occurred recently, leading to periods of time with sharply reduced reproduction. 
The lowest extinction risk was seen in the No-Operations scenario (dams present but not operated), for which the risk was less than $1.2 \%$ for all regions. In that scenario, relatively large amounts of habitat were created in the river reaches while reservoir shoreline habitat also remained available. The reservoirs were smaller, but the fluctuations in water level were greater, providing a wider expanse of unvegetated habitat. While high summer flows can occur in the No-Operations hydrograph, they are sufficiently attenuated by the outlet works of the dams that they do not limit significantly habitat availability in the southern region. In the north, habitat availability was reduced by more natural (flashy) summer flows (Figure 3), but the reservoir shoreline habitat buffered that variability and reduced the risk of extinction.

The Unregulated scenario (no dams) produced extinction risks between those of the Existing Conditions and No-Operations scenarios. The natural hydrograph was the most variable and was less attenuated downstream than the other scenarios. A large amount of habitat was created, but was inundated by summer flows more often, and in some cases it was available less often than the No-Operations scenario. Consequently, during a number of years less habitat was available in the southern region for the Unregulated scenario than for the No-Operations scenario. In the north, the Unregulated scenario included no reservoirs to serve as a buffer in years when riverine habitat was not available as there were in other scenarios. There was, however, considerably more miles of river, providing more habitat when summer flows were low. The years of abundant habitat resulted in high productivity for plovers, so the extinction risk was well below the Existing Conditions scenario. It was not, however, below the viability criteria of $5 \%$ risk of quasi-extinction in 50 years in either the northern or southern regions alone, though the northern region was close.

The Calibrated Target scenario was constructed to provide just enough habitat through mechanical creation to lower the extinction risk with the Existing Conditions scenario below 5\%. The amount needed for the southern region (Table 3) was higher than that needed for the northern region because of the relatively stable habitat provided by the reservoirs in the north. The target number for Garrison Reach depended on the productivity of plovers on the reservoirs; not only was the target value sensitive to model assumptions about productivity on the reservoirs, but significant changes in reservoir management could consequently affect viability in the region even if a similar amount of riverine habitat were available.

The distribution of habitat within the southern region between Fort Randall and Gavins Point Reaches was somewhat arbitrary, with emphasis on habitat construction in Gavins Point Reach. Roughly 20\% of the southern region acreage was constructed in Fort Randall Reach. Redistribution of habitat between the reaches may result in similar population outcomes.

The results of the sensitivity analysis for initial conditions and target acreages demonstrate why population viability and target approaches must be different for Missouri River plovers than for many other species. The plover recovery team model (McGowan et al. 2014) does not explicitly account for dynamic habitat availability, so the team was able to use a more standard approach. In this case, when habitat availability was explicitly modeled, population viability depended almost entirely on habitat availability, with very little dependence on initial population size in the southern region where only riverine and delta habitats are available. To achieve a specified level of population viability by altering an initial population size or habitat target, the range of extinction risks produced by changing the desired metric must be sufficiently sensitive to that metric; i.e., a line drawn through the resulting points must cross the viability criteria. A broad range of quasi-extinction probabilities above and below $5 \%$ can be produced by varying the target acreage, but very little probability range was covered by varying the population size for any given habitat amount.

Sensitivity of extinction risk was much more equivocal in the northern region because of the reservoirs; reservoir shoreline habitat was available to some extent in most years and was not affected by riverine habitat construction. The northern region population exhibited a narrower range of extinction risk overall 
and was more difficult to calibrate to a desired level of viability because of the reduced sensitivity to ESH creation. The overall population extinction risk combines the features of both regions and consequently was not as dependent upon initial population size as the north, nor as dependent on target acreage as the south. The range of overall extinction risk was generally lower than the combined risk of the two regions, which is to be expected because the likelihood of the combined population dropping below the quasiextinction threshold is lower than an individual region's population dropping below the threshold. Since the support of viable populations in each region is an objective, and a habitat target is necessary for the southern region and sufficient for the northern region, that approach is more effective than attempting to establish a population target alone.

The decision about which viability criteria to use (e.g., a $5 \%$ or $10 \%$ extinction risk, or a 50 - or 100 -year time frame) is a policy decision, not a scientific one, though arguments can be found in the literature for various approaches. Lower quasi-extinction probabilities and/or longer time frames are more risk-averse approaches, requiring more habitat to support populations in reaching those viability levels.

\subsection{Caveats}

Until very recently, there were no models to estimate ESH deposition and erosion as a function of flow. As part of the EA, in late 2014 an ESH model was developed to do so (Fischenich et al. 2014), but this model remains in early stages of development, and limited empirical data are available in reaches other than Gavins Point. While estimation error was incorporated into the habitat model, it remains possible that unknown biases exist in these models, especially under extreme conditions.

Strong caveats must be applied when using the ESH model for predictions outside of the conditions for which it was designed. The model was developed, parameterized, and verified using habitat conditions from 1998-2013. It is based upon the presence and operation of dams and reservoirs and contemporary channel morphology and sediment supply. In addition, while it was parameterized using information about the outcome of the 2011 flood on the formation of new ESH, it predicts the habitat formed by such an extreme event with more error than more moderate flow events (underprediction in this case, though the error decreases substantially in the months following the flood), and it is unknown how well the model would predict the outcome of more frequent high flows that could significantly alter sediment regimes or channel form, as in a natural hydrograph. It should also be expected that the model would be more uncertain when applied to reaches where ESH does not currently exist because of inundation in reservoirs, but would provide riverine habitat in the absence of dams and/or their operations as in the Unregulated and No-Operations scenarios.

The hydrologic model results in this report were based on a fairly limited period of record (83 years), and further, used consecutive years from that period of record to capture autocorrelation in flows. The period includes three major habitat-forming flows and some minor habitat-forming flows, as well as an extended drought (1930s) and several shorter droughts. By using sequences from this period of record, not only are the high and low flow events limited to those in this period of record, but the intervals between those events and the relationships between them (i.e., droughts following high flows) are fixed, and do not represent the full range of potential variability. This is one of several areas that the ESH model could be improved in the future.

Similarly, the plover population model was developed and parameterized for current conditions: estimates of the relationship between habitat availability, population density, and fledgling production are derived using data from 2005-2014 for riverine habitat and from 1993-2014 for reservoir shoreline habitat. Estimates for dispersal and survival are based on studies from within the past decade. While these data include 3 years of bird responses to flood-created habitat (2012-2014) as well as productivity during 
periods of low habitat quantity and quality (pre-2011), applying these relationships to historical and/or "natural" hydrographs assumes that no changes have occurred to plover habitat selection and reproductive timing or success in more than 50 years of a heavily modified riverine environment. Similarly, extrapolation of contemporary survival and dispersal rates to approximate historical conditions should be done with caution.

Plover population dynamics and extinction risk in the northern region is strongly affected by the assumptions made in the model of fledgling productivity on reservoirs. The model currently in use is based upon 21 years of productivity data and an evaluation of a number of potential hydrological and habitat metrics. It represents the best science currently available to predict fledgling production on the reservoirs. Both structural and parametric uncertainty remain in the model, however, and different assumptions about plover reproductive success on reservoirs would alter these results. A number of uncertainties remain in the model of plover fledgling production on ESH as well.

The current habitat and population models for the MRRMP include only the MRMS and not nearby habitats that can provide breeding habitat for plovers when habitat on the MRMS is scarce or provide a source of adult birds if breeding success on the MRMS is temporarily reduced. The population model assumes that dispersal to and from the MRMS is balanced and thus has no net effect on MRMS plover population dynamics. Little information was available during model development to model dispersal more specifically. As new information from ongoing studies becomes available about dispersal between the southern reaches and the Nebraska tributaries and between the northern reaches and the alkali lakes, the model could be improved to better handle these metapopulation dynamics. At this time, however, the effects of those other populations on MRMS population extinction risks are unknown. As with the productivity data above, the results of current studies may apply to a limited range of conditions. For example, the metapopulation study in progress began after the 2011 flood and thus represents a time period when habitat was abundant on the Missouri River; dispersal patterns may differ when habitat is scarce. Metapopulation influences on MRMS plover are an important area of research and should be addressed, as information becomes available, in ongoing adaptive management for piping plovers.

The results of this model application differ from those of the Piping Plover Recovery Team because of the difference in modeling approaches. The plover recovery team has modeled multiple plover populations in the Great Plains, including the northern and southern regions of the MRMS. That model does not, however, include habitat dynamics or density dependence and thus cannot reflect the findings of this study regarding the role of dynamic habitat availability in driving population dynamics.

\subsection{Population Targets}

Population recovery and management programs typically aspire to include quantitative population targets, which allow the status of the population to be assessed directly and for all management actions, including those that do not affect habitat, to contribute to achieving the target. In such programs, habitat targets may be used as a quantitative means objective that represents a necessary step to meet the fundamental objective of a population outcome. In this case, a sub-objective for the Missouri River Recovery Program (MRRP) is to maintain a total population number of Missouri River birds that keeps the population resilient on the Missouri River in the long term, and past ESH and bird management programs in the MRRP have included population targets. Making decisions about or recommendations for the use of habitat vs. population targets is out of the scope of this report. However, some considerations related to setting population targets using these models are briefly discussed below.

As demonstrated earlier in this report, population viability (for a resilient population) is driven more by habitat availability than by initial population size, and calculating a population size that will result in 
desired viability is either difficult (in the northern region) or impossible (in the southern region). Deriving a population number or even a stationary population distribution that allows for natural fluctuations from historical conditions is very challenging as well, because the ability to estimate historical conditions remains very limited and highly uncertain. Additionally, while habitat distributions under a given scenario stabilize into a stationary distribution in 10-20 years from any given initial conditions, modeled populations do not reach a stationary distribution for over 100 years. While we can calculate a long-term population distribution resulting from a given scenario, this distribution may not relate to population resilience (because populations may not stabilize within the time frame of the viability metrics) and may be difficult to employ as a practical target for management.

A population distribution can, however, be provided for any given management scenario as long as the time frame is also specified. For example, the Calibrated Target scenario produces both ESH distributions (presented in this report) and associated population distributions (not shown) for any given time point in the simulation (e.g., 10, 20, or 50 years). When comparing a proposed management scheme to the target, ESH distributions can be compared to determine whether the target is met. This would not, however, reflect management actions on the reservoir shorelines or directly address population needs (e.g., predation management). To do so, the population distributions can be compared along with habitat distributions. The key difference is that while habitat distributions are not time-sensitive after 10-20 years, population distributions are. Consequently, there is not a single meaningful distribution that can be defined to be used into the future. There can, however, be a target distribution specified for a time frame against which management alternatives can be compared. For example, the population distribution produced by the Calibrated Target scenario, beginning in the current year and ending in a specified future year, could be produced for each option to determine whether populations will respond as well to a management alternative as they do to the Calibrated Target scenario. This approach, while more complex, is practicable and supported theoretically by the findings of this report. Other solutions may also exist.

\subsection{Acknowledgments}

This work was funded by the Missouri River Recovery Program, U.S. Army Corps of Engineers, Omaha District, as part of the Missouri River EA. The work was done in coordination with Casey Kruse and Carol Smith (USFWS). Craig Fischenich (USACE Engineer Research and Development Center Environmental Laboratory) provided the ESH models and review of some of the modeling in this report. Ryan Larsen and Alex Flanigan (USACE) provided HEC-ResSim output. Nichole Sather (PNNL) assisted with production of figures and review of the report, and Susan Ennor (PNNL) provided technical editing. Carol Aron (USFWS) and Conor McGowan (USGS) provided information on the criteria and models being used by the Piping Plover Recovery Team. Helpful feedback on target development was received from members of the Independent Science Advisory Panel: Dennis Murphy, Adrian Farmer, Steve Bartell, Martin Doyle, Chris Guy, and Gary Lamberti; and the Third Party Science Neutral, Robb Turner.

\subsection{References}

Anteau, MJ, TL Shaffer, MH Sherfy, MA Sovada, JH Stucker, and MT Wiltermuth. 2012. "Nest Survival of Piping Plovers at a Dynamic Reservoir Indicates an Ecological Trap for a Threatened Population," Oecologia, 170(4):1167-1179. doi:10.1007/s00442-012-2384-y.

Anteau, MJ, MT Wiltermuth, MH Sherfy, and TL Shaffer. 2014. "Measuring and Predicting Abundance and Dynamics of Habitat for Piping Plovers on a Large Reservoir," Ecological Modelling, 272(0):16-27. doi:http://dx.doi.org/10.1016/j.ecolmodel.2013.08.020. 
Buenau, K, V Cullinan, C Huber, and C Vernon. 2014. Draft Interim Effects Analysis Integrated Report, Pacific Northwest National Laboratory.

Buenau, KE, TL Hiller, and AJ Tyre. 2013. "Modeling the Effects of River Flow on Population Dynamics of Piping Plovers (Charadrius Melodus) and Least Terns (Sternula Antillarum) Nesting on the Missouri River," River Research and Applications:n/a-n/a. doi:10.1002/rra.2694.

Fischenich, JC, R Mccomas, D Meier, J Tripe, D Pridal, P Boyd, S Gibson, J Hickey, T Econopouly, and L Strong. 2014. Habitat Analysis for the Missouri River Effects Analysis -- Geomorphic Team Integrative Report, USACE ERDC-EL.

Mcgowan, CP, DH Catlin, TL Shaffer, CL Gratto-Trevor, and C Aron. 2014. "Establishing Endangered Species Recovery Criteria Using Predictive Simulation Modeling," Biological Conservation, 177(0):220229. doi:http://dx.doi.org/10.1016/j.biocon.2014.06.018.

USACE. 2006. Missouri River Mainstem Reservoir System Master Watercontrol Manual: Missouri River Basin, N.D.O. Us Army Corps of Engineers, Nebraska.

USFWS. 2003. Amendment to the 2000 Biological Opinion on the Operation of the Missouri River Main Stem Reservoir System, Operation and Maintenance of the Missouri River Bank Stabilization and Navigation Project, and Operation of the Kansas River Reservoir System., U.S. Fish and Wildlife Service, Fort Snelling, Minnesota.

USFWS. 2000 Biological Opinion on the Operation of the Missouri River Main Stem Reservoir System, Operation and Maintenance of the Missouri River Bank Stabilization and Navigation Project, and Operation of the Kansas River Reservoir System., U.S. Fish and Wildlife Service, Fort Snelling, Minnesota. 
Table 1. Summary of hydrological inputs, reach and reservoir definitions, and habitat construction in target modeling scenarios.

\begin{tabular}{|c|c|c|c|c|}
\hline Scenario & Hydrology & Reaches & Reservoirs & $\begin{array}{c}\text { Habitat } \\
\text { Construction }\end{array}$ \\
\hline $\begin{array}{l}\text { Existing } \\
\text { Conditions }\end{array}$ & $\begin{array}{l}\text { Current Master } \\
\text { Manual operations }\end{array}$ & $\begin{array}{l}\text { Garrison, Fort Randall, } \\
\text { Lewis and Clark delta, } \\
\text { Gavins Point. }\end{array}$ & $\begin{array}{l}\text { Reservoir shoreline } \\
\text { habitat on Lake } \\
\text { Sakakawea and Lake } \\
\text { Oahe. }\end{array}$ & None \\
\hline $\begin{array}{l}\text { No } \\
\text { Operations }\end{array}$ & $\begin{array}{l}\text { Dams exist but are } \\
\text { not operated; run } \\
\text { of river impeded } \\
\text { only by limitations } \\
\text { of outlet works. }\end{array}$ & $\begin{array}{l}\text { Upper Sakakawea, } \\
\text { Garrison (extends } \\
\text { through drawn down part } \\
\text { of Oahe), Fort Randall, } \\
\text { Lewis and Clark (all } \\
\text { riverine), Gavins Point. }\end{array}$ & $\begin{array}{l}\text { Reservoir shoreline } \\
\text { habitat on Lake } \\
\text { Sakakawea and Lake } \\
\text { Oahe, which fluctuate } \\
\text { around the permanent } \\
\text { pool. Reservoir } \\
\text { elevations track river } \\
\text { stage fluctuations. }\end{array}$ & None \\
\hline Unregulated & $\begin{array}{l}\text { No dams, run of } \\
\text { river }\end{array}$ & $\begin{array}{l}\text { Sakakawea, Garrison } \\
\text { (includes Oahe), Sharpe, } \\
\text { Francis Case, Fort } \\
\text { Randall (includes Lewis } \\
\text { and Clark Lake), Gavins } \\
\text { Point. }\end{array}$ & None & None \\
\hline Calibrated & $\begin{array}{l}\text { Current Master } \\
\text { Manual operations }\end{array}$ & $\begin{array}{l}\text { Garrison, Fort Randall, } \\
\text { Lewis and Clark delta, } \\
\text { and Gavins Point. }\end{array}$ & $\begin{array}{l}\text { Reservoir shoreline } \\
\text { habitat on Lake } \\
\text { Sakakawea and Lake } \\
\text { Oahe. }\end{array}$ & $\begin{array}{l}\text { Built to model } \\
\text { targets of } 670 \\
\text { acres in Gavins } \\
\text { Point, } 100 \text { acres in } \\
\text { Fort Randall, and } \\
500 \text { acres in } \\
\text { Garrison Reach }^{\text {(a) }}\end{array}$ \\
\hline $\begin{array}{l}\text { (a) Model h } \\
\text { and are } \\
\text { scenario }\end{array}$ & 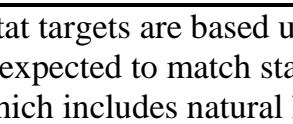 & floc & ate how much hab & $\begin{array}{l}\text { leeds to be built, } \\
\text { librated Target }\end{array}$ \\
\hline
\end{tabular}


Table 2. Model specifications by river segment for each scenario. The Existing Conditions specifications also apply to the Calibrated Target scenario. Gray cells indicate that a segment was not defined for a particular scenario. All flows are dam outflows unless otherwise specified.

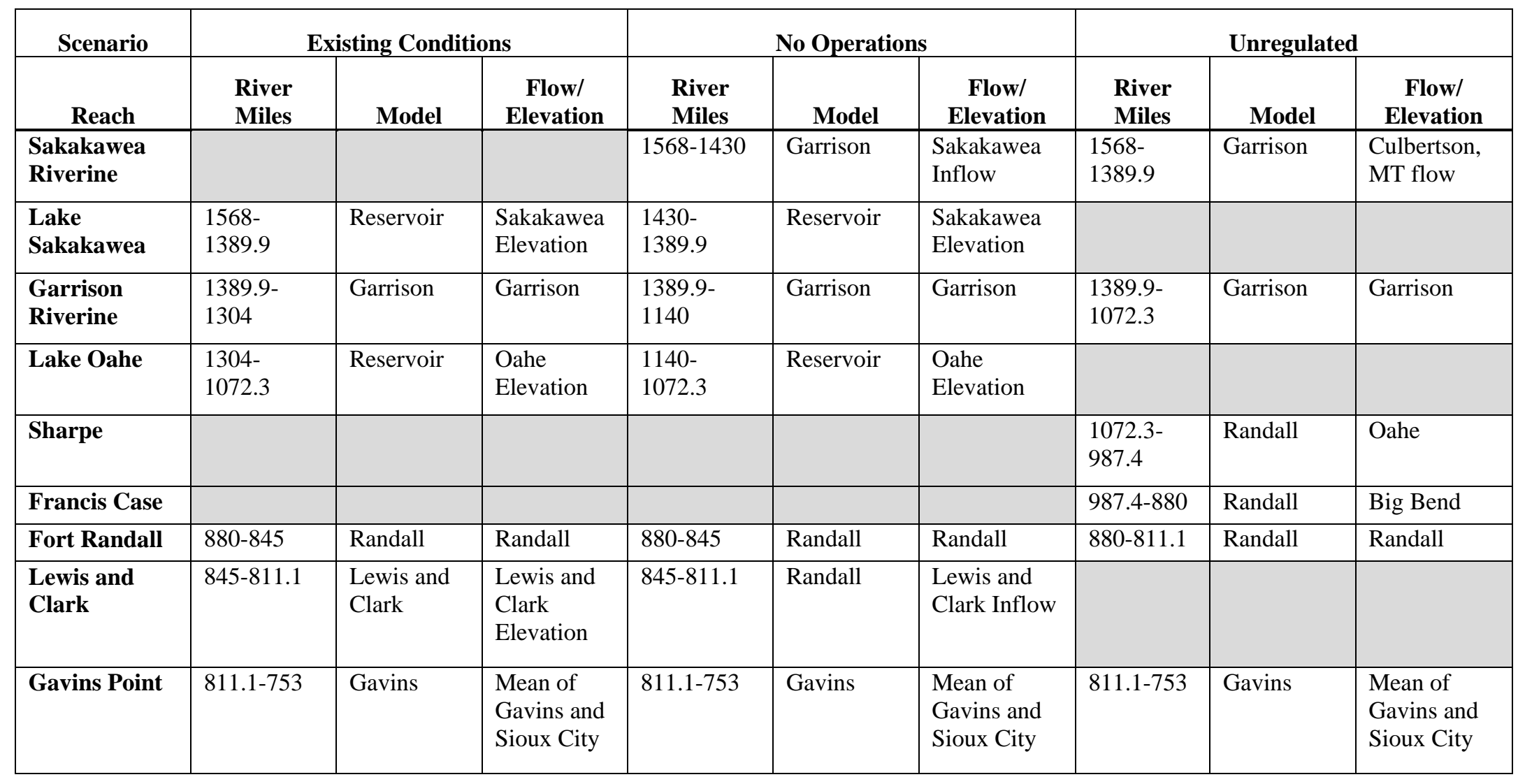


Table 3. Distribution of standardized habitat for scenarios (specified percentile acres, averaged over last 30 years of simulations). Standardized acres are those available at 23.9 kcfs for Garrison Reach, 30.5 kcfs for Fort Randall Reach, and 31.6 kcfs for Gavins Point.

\begin{tabular}{|c|c|c|c|c|c|c|c|c|c|}
\hline & \multicolumn{3}{|c|}{ Both Regions } & \multicolumn{3}{|c|}{ Northern Region } & \multicolumn{3}{|c|}{ Southern Region } \\
\hline Percentile & 2.5 & 50 & 97.5 & 2.5 & 50 & 97.5 & 2.5 & 50 & 97.5 \\
\hline $\begin{array}{l}\text { Existing } \\
\text { Conditions }\end{array}$ & 17 & 768 & 5,733 & 0 & 106 & 1,635 & 3 & 370 & 4132 \\
\hline Unregulated & 33 & 9,450 & 384,393 & 7 & 7,634 & 362,331 & 18 & 858 & 29,121 \\
\hline $\begin{array}{l}\text { No } \\
\text { Operations }\end{array}$ & 6,782 & 12,477 & 20,360 & 4,230 & 8,630 & 15,103 & 746 & 2,783 & 7,306 \\
\hline Calibrated & 675 & 1,433 & 6,033 & 200 & 428 & 1,996 & 264 & 782 & 3,907 \\
\hline
\end{tabular}

Table 4. Distribution of standardized habitat for different population viability criteria (means of specified percentile acres over last 30 years of simulations). Standardized acres are those available at 23.9 kcfs for Garrison, 30.5 kcfs for Fort Randall, and 31.6 kcfs for Gavins Point Reaches.

\begin{tabular}{|l|c|c|c|c|c|c|c|c|c|}
\hline & \multicolumn{3}{|c|}{ Both Regions } & \multicolumn{3}{c|}{ Northern Region } & \multicolumn{3}{c|}{ Southern Region } \\
\hline \multicolumn{1}{|c}{ Percentile } & $\mathbf{2 . 5}$ & $\mathbf{5 0}$ & $\mathbf{9 7 . 5}$ & $\mathbf{2 . 5}$ & $\mathbf{5 0}$ & $\mathbf{9 7 . 5}$ & $\mathbf{2 . 5}$ & $\mathbf{5 0}$ & $\mathbf{9 7 . 5}$ \\
\hline $\mathbf{5 \% , 5 0}$ years & 675 & 1,433 & 6,033 & 200 & 428 & 1,996 & 264 & 782 & 3,907 \\
\hline $\mathbf{1 0 \% , 5 0}$ years & 285 & 1,024 & 5,948 & 2 & 158 & 1,920 & 116 & 607 & 3,943 \\
\hline $\mathbf{5 \% , 1 0 0}$ years & 2,046 & 3,390 & 6,980 & 1,017 & 1,944 & 3,401 & 518 & 1,161 & 4,076 \\
\hline
\end{tabular}




\section{Garrison Dam}
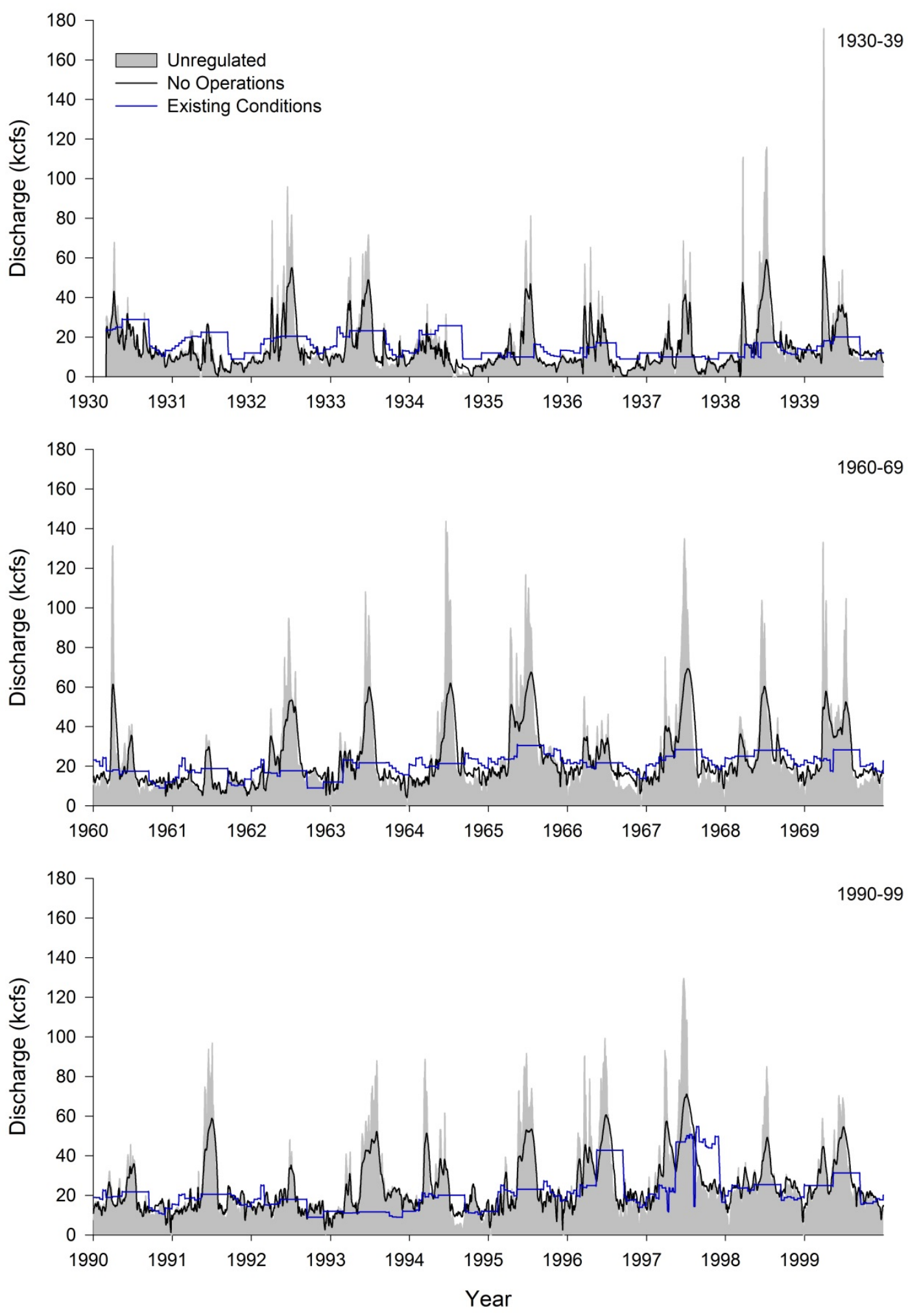

Figure 1. Daily discharge from Garrison Dam for three representative decades for the Unregulated, Existing Conditions, and No-Operations scenarios. 


\section{Gavins Dam}
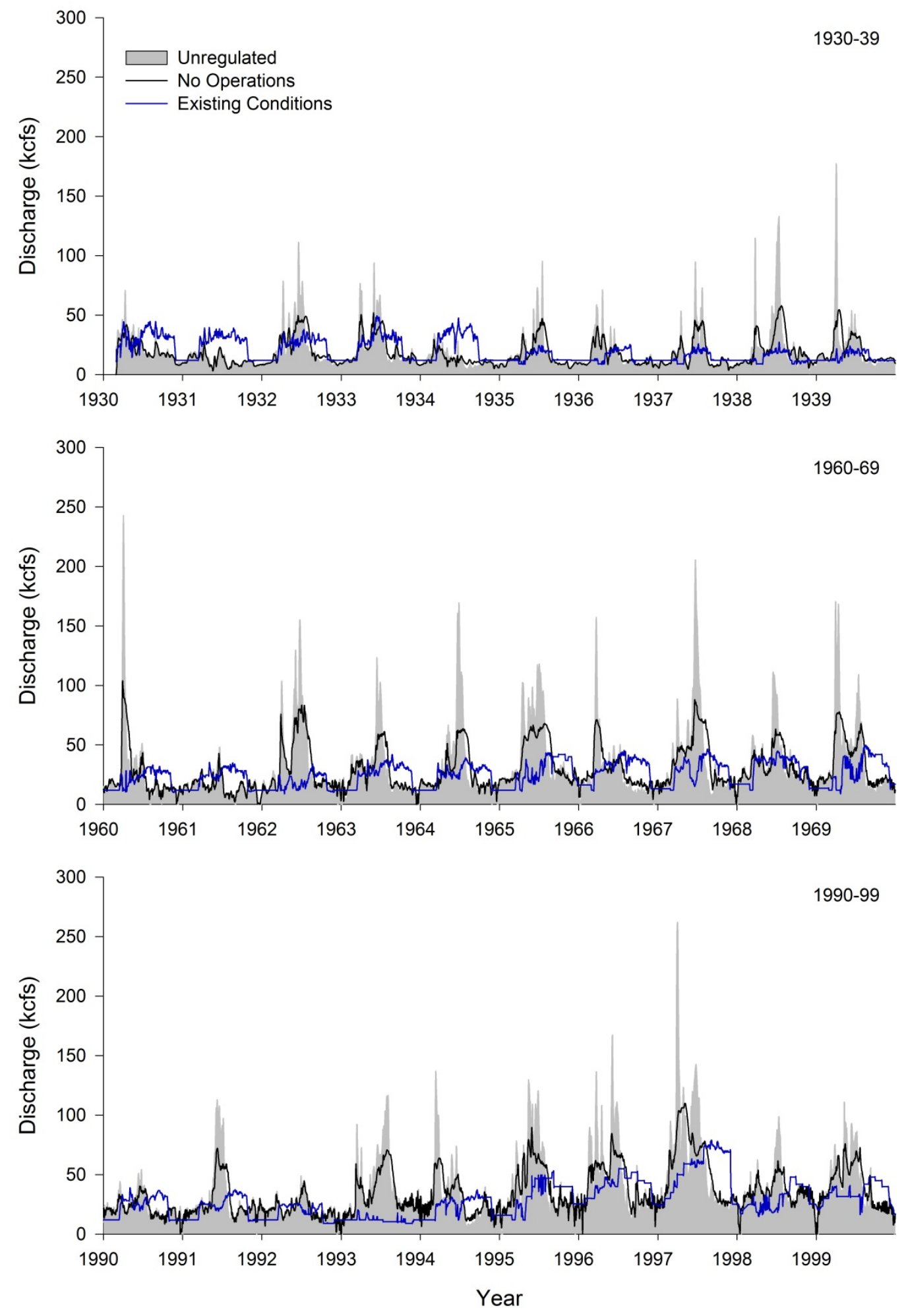

Figure 2. Daily discharge from Gavins Point Dam for three representative decades for the Unregulated, Existing Conditions, and No-Operations scenarios. 


\section{Existing Conditions}
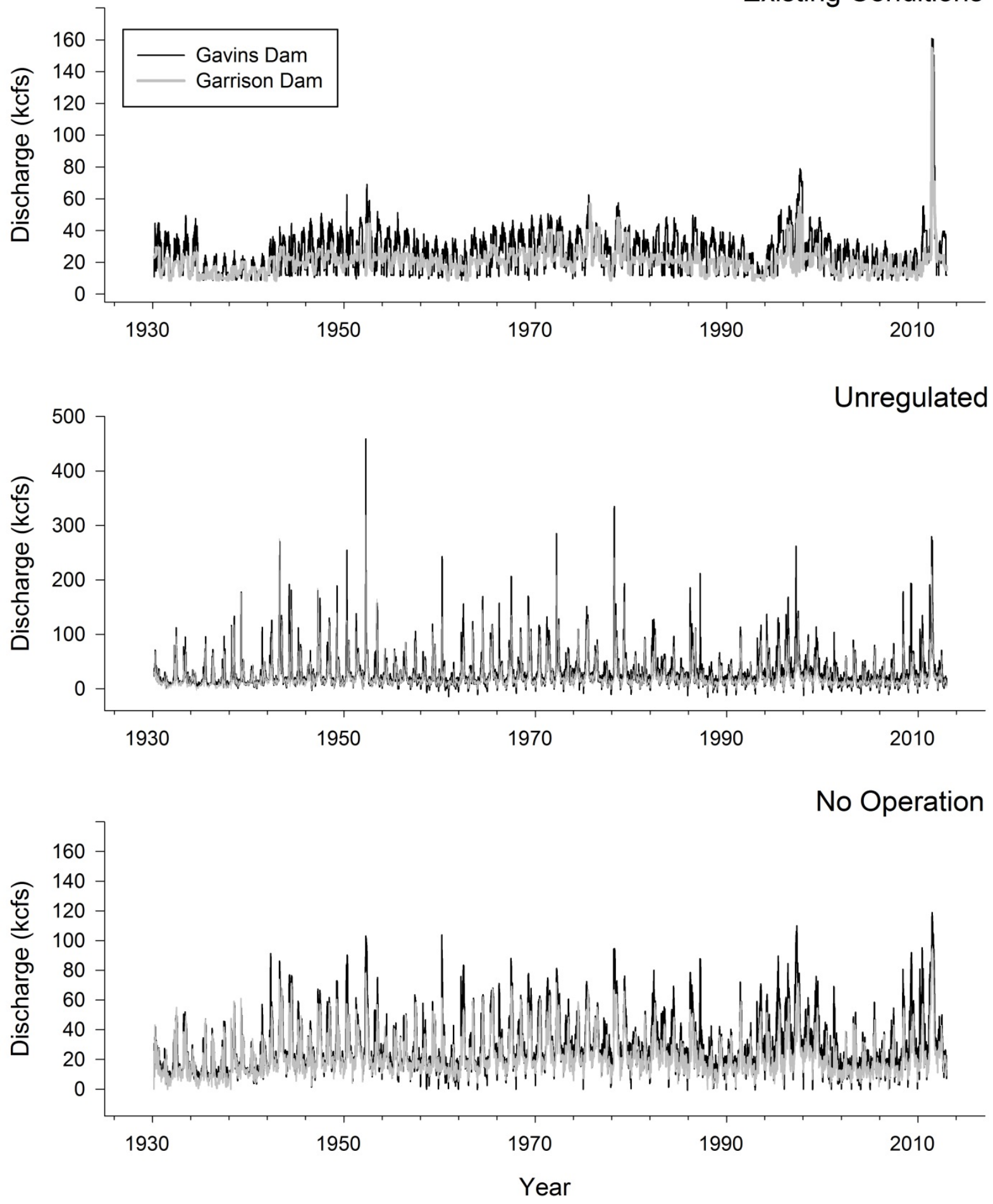

Figure 3. Comparison of discharges from Gavins Point and Garrison Dams for the Existing Conditions, Unregulated, and No-Operations scenarios. Note change in y-axis for the Unregulated scenario. 

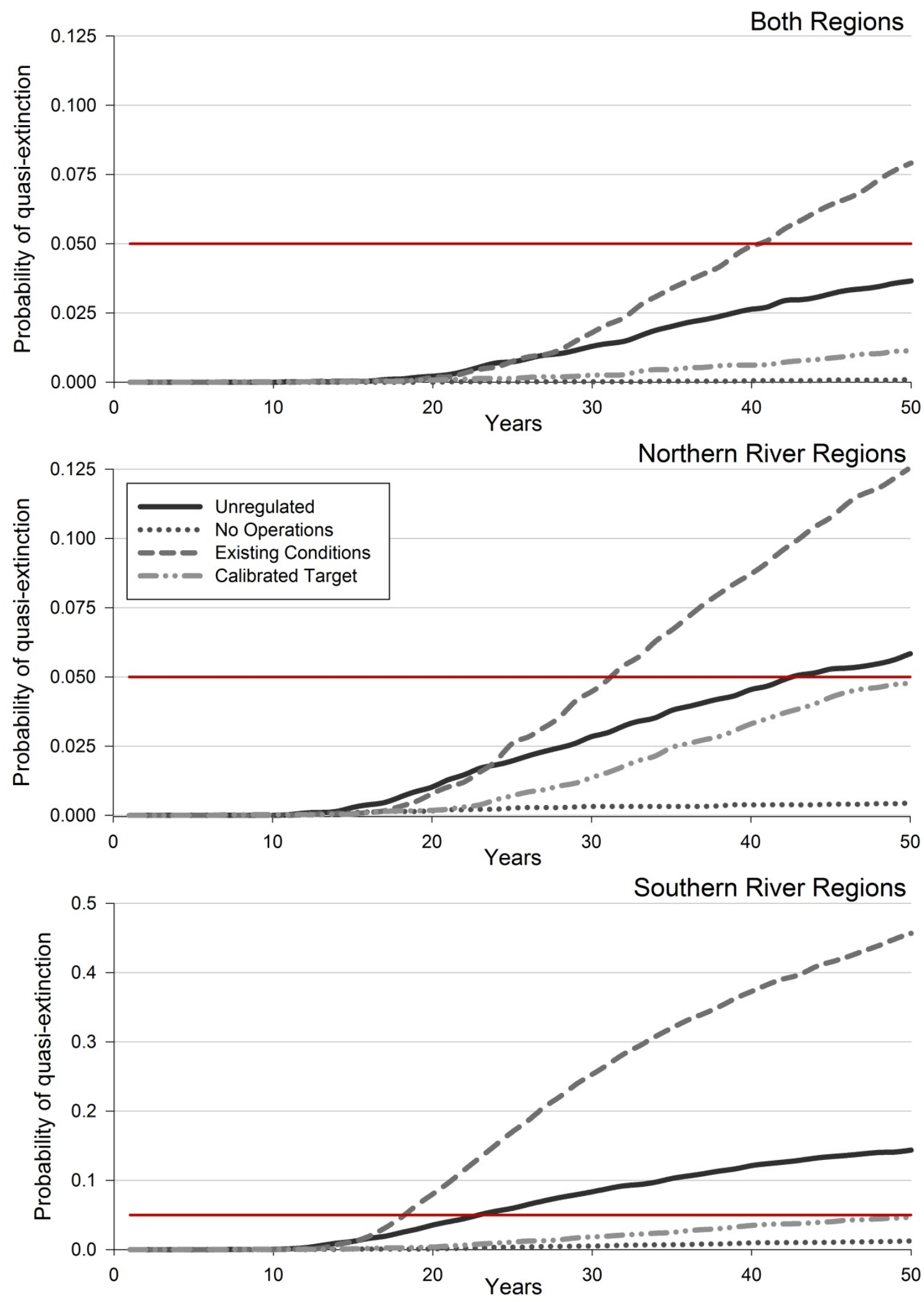

Figure 4 .Probability over time of quasi-extinction of the plover population for a) both regions, b) the northern region, and c) the southern region. Note difference in y-axis scale for the southern region. 

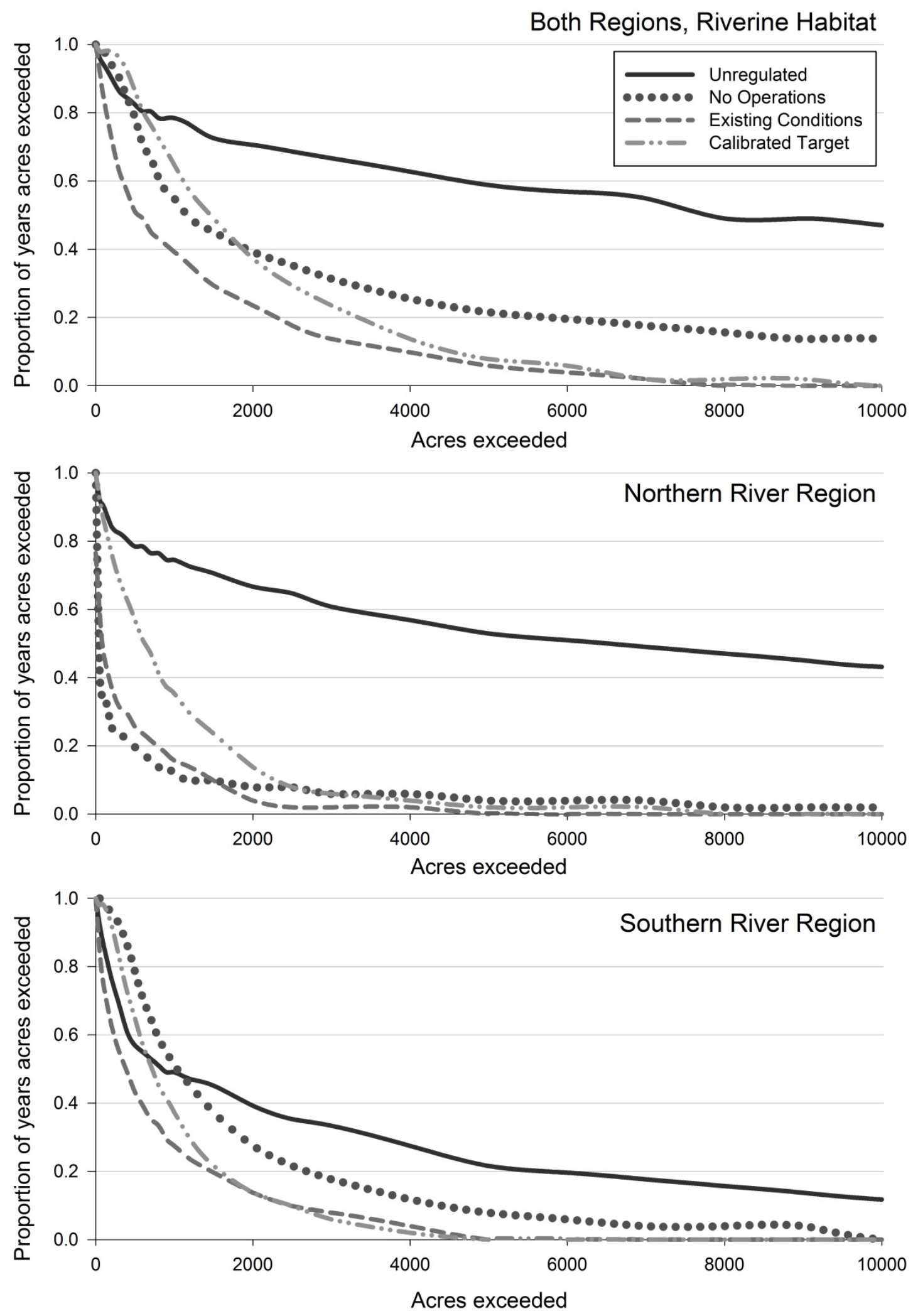

Figure 5. Likelihood that available habitat exceeds a given acreage for target scenarios for a) both regions, b) the northern region, and c) the southern region. 

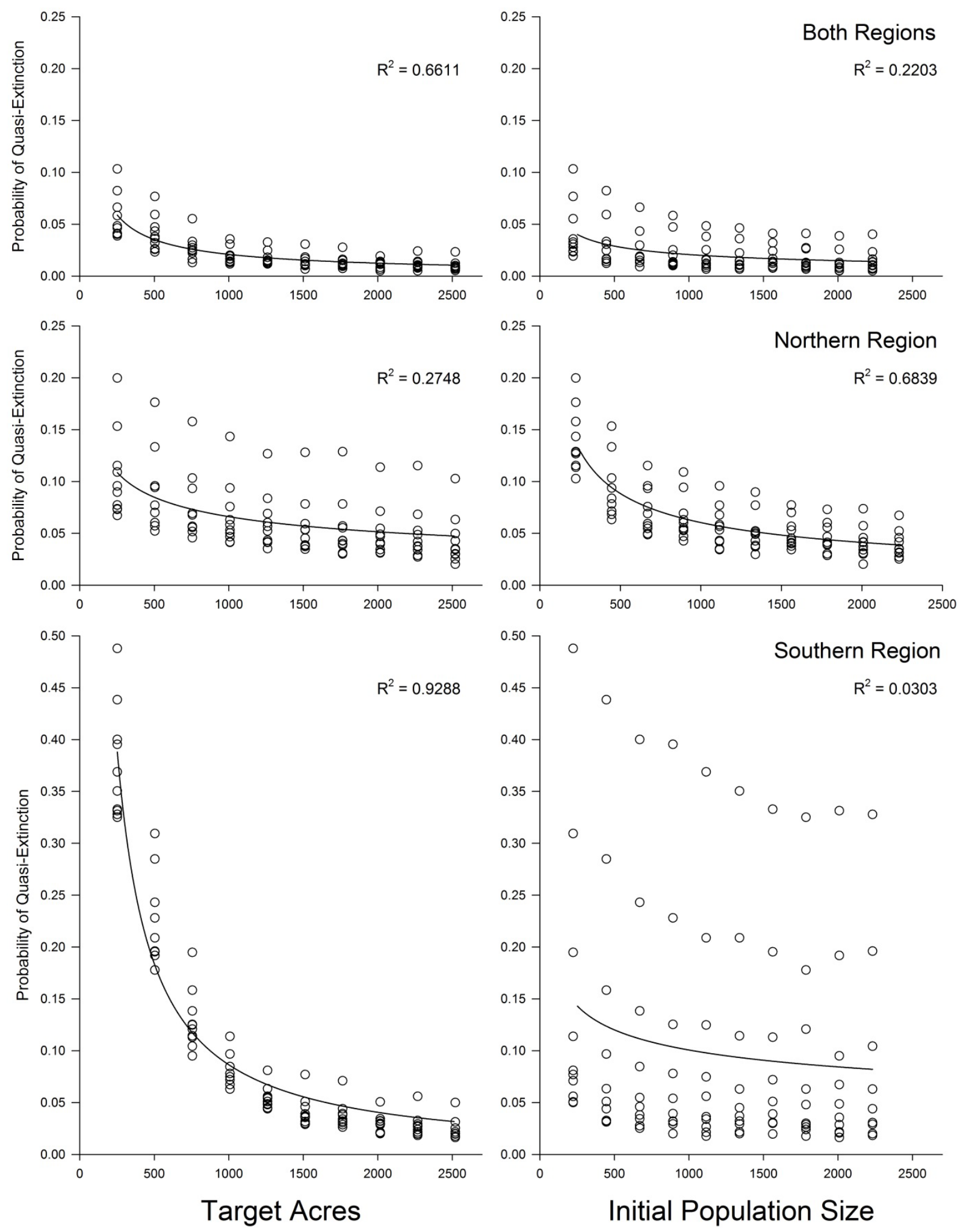

Figure 6. Sensitivity of probability of quasi-extinction to target acreage and initial population size. 

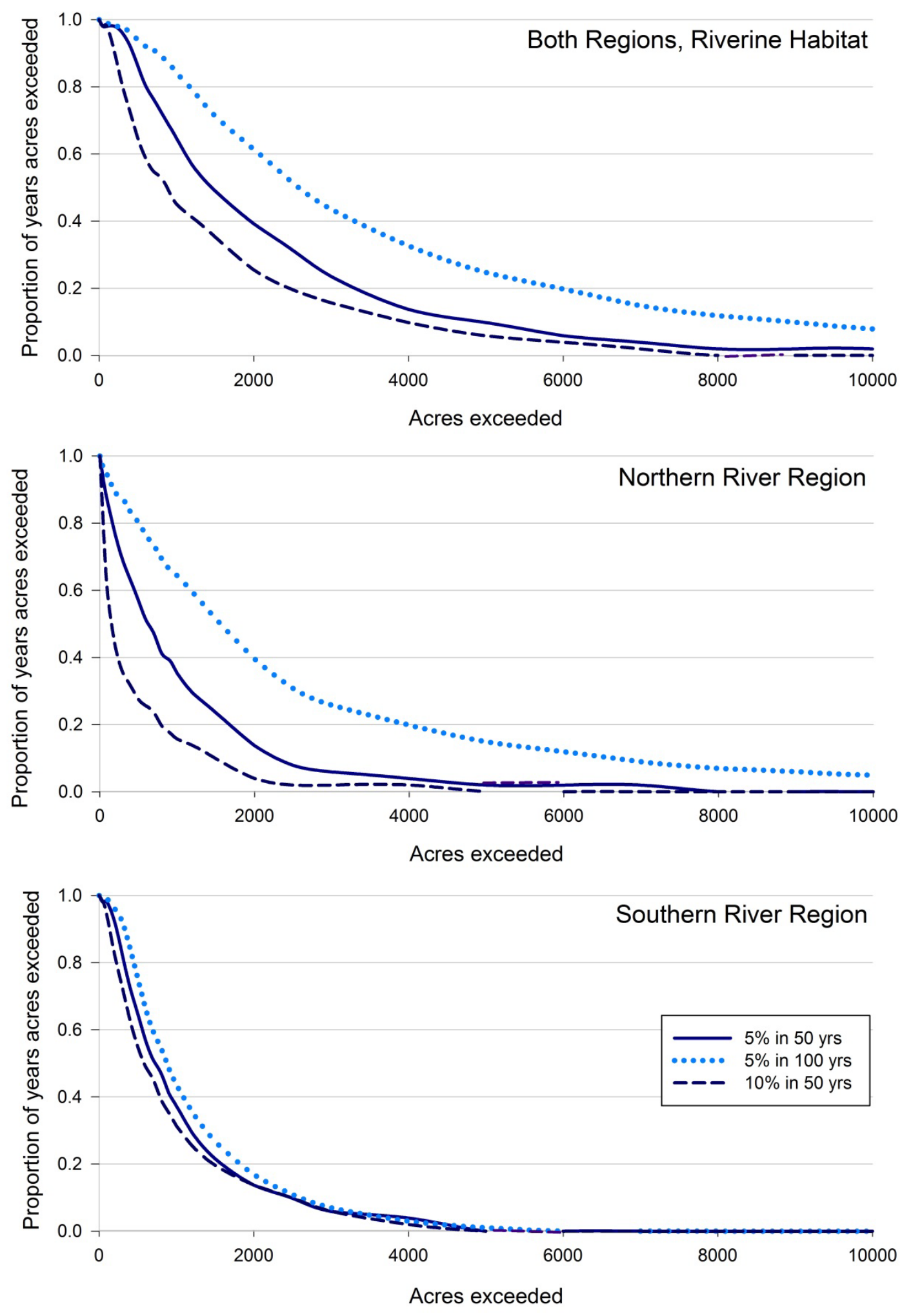

Figure 7. Likelihood that available habitat exceeds a given acreage for different viability criteria for a) both regions, b) the northern region, and c) the southern region. 